\title{
Do We Need Surrealism Nowadays?
}

\author{
Prof. Assoc. Dr Maklena Nika \\ Department of Greek Language, Faculty of Foreign Languages, University of Tirana, Albania
}

\begin{abstract}
Even though 90 years have already passed form the First Surrealism Manifest (1924) of Andre Breton, it seems as if surrealism is still actual and tangible even nowadays. If we study it deeply theoretically, it is obvious that it is necessary in the century we are living. The surrealists' human commitment becomes more attractive in an époque that is becoming materialistic day by day, in a society that hands in its fate to science and technology and in an environment which is getting more and more hostile every day. In this framework, surrealism is perceived neither as a "dogma" nor as a closed philosophical system, but as an open and adapted thought and life confrontation "method". It has got a relieving effect which makes people co-communicate among each other; people of all the nationalities who gather around a common inspiration. It unifies the past with the present; it engraves the boulevard of the future, offering new and unknown opportunities to anyone.
\end{abstract}

Keywords: Surrealism, Nowadays

\section{Introduction}

Time passes and everything changes... Time itself changes, and so does the man, his mind, his thoughts, his concepts, his perceptions, his feelings and his ways of expressing himself... It seems as if everything has taken a new shape in the century we are living, and unconsciously, every day, we search a new expressing means for our spirit, because there are several ones at our disposal, but sometimes we refer to the past to find the most significant means for the spiritual inner needs. The artists, but even simple people are aware that modern art was the best way to express the opposition against reality and every conventionalism that surrounds the man. Surrealism, as one of the best organized movements, would have an undisputable artistic, literary, political, social and psychological role in this modern art.

\section{What is surrealism?}

Surrealism is considered as a literary and artistic movement of the 20th century. Along with Dadaism, they have emerged being provoked by the First World War. It is clearly distinguished from other movements by the trend and inclination to appear as a comprehensive system of ideas and principles, whose essence is not defined solely in literary and artistic expression, but in all respects, in order to provide a fuller interpretation of the world. To discover the world of unconsciousness, supporting the explanatory principle of the reliable records of irrational situations, such as dreams, spiritual automata, and psychopathic associations.

It is an anti -mystic surrealism that cannot be established beyond this world, nor beyond our time of life. Paradoxically, it is inherent, exists within human beings and greatly presents the dark sides of each individual (Philippe Van Tieghem). ${ }^{1}$ Reflecting on surrealism, both from the aesthetic and metaphysical point of view, means capturing its poetic ideas, revolting

${ }^{1}$ Chassang Arsene, Senninger Charles, La Disertation Litteraire Generale, Volume 2, Publications Hachette, Paris 1993, Chapter XII, Le surrealisme, pg. 331 
attitudes and shameless experiences, dreams, coincidence, love, action, image, language and so on. It means exploring another world, finding the key to a superior universe of the Absolute of Balzac's time.

Thus, surrealism opened up a field of radical renewal both in the personal and collective human life, as well as in the development of thought, morality and art. Surrealism, defined by $A$. Breton, was intended to reconsider the definition of reality ${ }^{1}$. The instruments it used, automatic writing, dreams recording, narrations under a state of hypnosis, poems, and paintings created by occasional influences, art that reflected absurd and dreamy scenes, all had been invented to serve the same basic goal - change of our concept of the world and change of this world. As Breton explained, "We live in the heart of modern society, which relies on such a serious reconciliation that all its exaggerations are justified" 2

\section{The Essence of Surrealism}

Art should be oriented towards the expression of the wish to strengthen the foundations of reality as much as possible. At this point, we would refer to "Surrealism Manifest" which preaches the provocation of the world consciousness, which is even crazier, and which we perceive via our senses. The surrealists, who apart from the artistic expression preserved fanatically even the political one, did not support the realistic character of art, but the spiritual one, processing Rimbaud's principle that the poet should become a prophet, the prophet of love and crazy pain. One of the artist's obligations is to believe in miracles, as "what is wonderful is always beautiful, every wonderful thing is beautiful" according to the surrealists. XX century will have, to some extent, the tendency towards one single art and religion, through a prevailing character. Every artist should respect his own self and the free artistic creation. In this way, even art will preserve the prophetic character and human variety and the genuine pluralism, which stems from the consciousness of the common human destiny.

The sharp morale was evident among the surrealists. It did not leave space for hypocrisies and unreasoned disdain of a society which considered the social order as a priority with regard to human behavior integrity. For a surrealist, a passionate rush will always be a step higher than a calculated brutality, a spontaneous gesture in art and in life, better than a wellstudied plan. In an époque which becomes more materialistic day by day, in a society which infinitely bestows its destiny to technology and science, in an environment which becomes more and more hostile day by day, the surrealists' human zeal becomes more attractive. The supernatural still plays a certain role to explain to the man his own self and to oppose the arrogant theory, if supposedly the man's attitude and his universe expansion might be measured. As Aragon would reflect at "The countryman from Paris":

Is it possible that at some certain time the knowledge, which stems from the logic, might be compared to the esthetic knowledge? Undoubtfully, brutal people, who refer only to this one and despise the other one, give some explanations to me about the distain it has degraded to, and that it originates from the senses. But when the wiser ones learn that the light is a tremble, what my eyes teach to me about the light, what differentiates me from the blind, and that is connected to the miracle, is not a logical object at all.

At this point, the essence of surrealism and the guaranty for its continual relevance can be found. Surrealism is not a "dogma", not a philosophical enclosed system either, but it is an open and adjusted thinking and life confronting method. It is an attempt to recreate "the spread consciousness of time in an "ensemble" which accepts continuously reconceptions and enrichment with new elements and data-it is a synthesis of several ideas from the inside, and its sources are a lot outside. Exactly within this definition, we should also explain the scientific concern of surrealism, making use of scientific data, aiming to build surrealist science and put it in service of their project, which consisted of the total liberation of human beings in the capitalist world.

\footnotetext{
${ }^{1}$ As above, pg. 60

2 Browder Clifford, "Andre Breton: Arbiter of Surrealism", Publications Droz, 1967, pg. 21.
} 


\section{Today's globalism of surrealism}

We may say that a "globalism" exists in the middle of surrealism, because it is understood and accepted by people, despite their age or race, despite their education or the group they come from. It has a liberating influence, which makes people communicate among them, people from all nationalities, who are united around a common inspiration. It reunites the present and the past, it carves the far away boulevard of the future, offering new and unknown opportunities to everyone. Surrealism is made of ideas conjugations which complete each other dialectally. It is an "annexing" attempt of the thinking zones which are still unknown. It is an attempt to reconnect the man with his own-self and the surrounding world elements, he was separated from, by the so-called "progress of our civilization", that means a reunion with his real wishes and emotions. This does not mean that surrealism is against "the improvement of the survival conditions of man"; on the contrary, according to Marx, we have to "transform the world", but even according to Rimbaud we have to "change our life"'.

Rimbaud responded to this cause through his own life, accomplishing his poetic mission at the age of 24. He went to the East in search of that first and enlightening truth. He left to his successors a great message - Real life does not exist, and he wanted to win exactly this life, the life of absolute freedom of soul, where action, poetry and dream form an absolute reality that probably constitutes the lost unity of modern world.

Building life through poetry was the leitmotiv of surrealists, which meant to explore new ways to know the so-called objective reality. However, this duty would not be only of the poets, but of all the world. According to Lautreamont, poetry should be created by everyone.

Which will be the role of the beautiful in this poetry? Beauty should be convulsive ${ }^{2}$, wrote Andre Breton and dream, revolt, alchemy of the word and reversal of rules of the beautiful and logical rule, laughing constitute the arsenal of the emerging poet at the dawn of the twentieth century. This arsenal would comprise of very strong images-objects that may arise from a comparison, but also from the approximation of two realities distant from each other. The farther these two realities are from each other, the more this image will have an emotive strength and poetic reality 3 .

This new empire of images was not addressed only to poets, but to all people. Because it was about turning all the old, sublimated and mystified images of the European bourgeoisie after the French Revolution into divine ones, such as justice, equality, peace, freedom. It was about turning them into real images, specifically, to make the artist function through his artistic activity within this space... ${ }^{4}$

\section{Surrealist phenomenology}

We may say that globalism awareness is an undisputable condition of art. Every artistic masterpiece transmits the consciousness of the common human destiny. "Gilgamesh Epic" or "Odyssey" of Homer are not just a registration of the mythical genealogy or the ancient history of a nation, but they reveal accurately the their human character through the human adventure of a certain man: the hero of these mythical eposes. Giannis Tsarouchis stated: "An artistic work is a tree that expands its branches all over the world, deeply rooted in its place". He wanted to describe the antithesis which exists between human adventure in the world, through one single hero and his destiny.

If we carried out a research from the XV to XX century, we would notice the same perception of man and his product, the artistic work. In the modern literary and artistic trends of the XX century, particularly in cubism and surrealism, we would find a strong presence of art's and man's globalization. Meanwhile, we should consider the fact that only in freedom can

\footnotetext{
${ }^{1}$ Rimbaud Arthur, Une saison en enfer, in Works, Publications Garnier, Paris 1960, pg. 225

2 Breton Andre, L' amour fou (1937), Publications Gallimard, Paris 1976, pg. 15

${ }^{3}$ Reverdy Pierre, L image, published in the Magazine Nord-Sud, No. 13, March 1918, in Nord-Sud, Self-Defense et autres ecrit sur / art e la poesie (1917-1926), Publications Flammarion, Paris 1975, pg. 73

${ }^{4}$ Benjamin Walter, Mythe et Violence, Publications Gallimard, Paris 1986, pg. 35
} 
art give the right products. Science and art do not have boundaries; the surrealists knew this fact very well. They preached only the freedom in the artistic expression via the automator writing.

The elements surrealism is able to provide us with, are the heraclitian search for a point of our spirit, "where life and death, the reality and the imaginary, the past and the future, the transmittable and the non-transmittable, the bottom part and the sublime are not perceived according to a contradictory way anymore" (Second Manifest):

"It would be in vain", Breton adds, "to give to surrealism just a destroying and constructing sense. Even this is a conjugation of the opposite meanings, like the construction and the destruction, which cannot be positioned in front of each other by anyone." (Second Manifest)

"What can those, who still preserve some knowledge about their position in this world, profit from the surrealist experience?". "The real position of man is inside himself, it is a hazardous recognition, but we think it is even supreme for our own self" (Second Manifest).

For this reason, as Hegel's admirer, he applies his dialectic system in the analysis of spiritual emotions and situations. He creates a phenomenology of "eros" and concretizes a special method, which loses partially when it is applied only on abstract meanings. In the same way, from Freud he gets the most important keys, such as the dreams analysis, the "penetration" method in the codified world of the spirit, composed of symbols, analogies and transfers. In the majority part, he does not accept the "mechanic basis" of his theories, and even the "complexes theories", not regarding their formulation, but regarding the relevant conclusions. He completes the psychoanalysis with the metapsychic without falling into mysticism or into a belief without the "value. The surrealist war against the mentality that existed in literature and in the logics in general, is carried out with words, and then with images: "The overturn of the way man feels, nowadays cannot be achieved only with the articulation of the logical phrase" (Second Manifest).

At this point, Engels's thought, which is emphasized by Breton, is quite similar to Heraklit's and Lao Ce's thought. They are two major dialectic systems of the antiquity. The spirit is free and not free, it is influenced by its environment and is not influenced, it opens new ways and continues its own one. These tragic conditions of the spirit are reflected very heartedly in the philosophical and poetic works of Hegel, Foierbah, Marx, Lautreamont, Rimbaud, Tzara, Freud, Caplin, Trotsky, Nitzsche, Dostoyevksy, Kafka, Jung and many other ones who are concerned about this drama: our époque thought. Surrealism objects openly the free use of the language or the insufficient definitions which create suspicious spaces around them. Surrealism is becoming free from the medieval scholasticism ropes, it is a fresh wind of Paganini's understanding, "it is a tragic expression of life", it is the "mythization of the world", it is the eternal research of the truth. Where is the truth? Within this mess of these opposing ideas which existed about every above mentioned topic, surrealism makes a heroic and desperate attempt, to form its own idea, despite the fractions, the feelings, interests or the accepted ways of the thought.

The importance of surrealism lays exactly in this effort for independence, which at first sight seems to be easy, but which might actually be the most "inaccessible", the most challenging thing in our époque - today everything stiffens and roughens - everything is created in mentalities - tendencies - thinking directions and systems - among which every avoidance exception, "every heresy" is a synonym of "crime".

\section{Misunderstandings and misinterpretations}

Generally, the shallowness of the criticisms in connection with "surrealism" phenomenon might have even unconscious causes. In other words, they might be the reactions of those people who do not want or are afraid to contact their own self "deeper", or afraid of what the surrealism techniques might reveal (exactly like the neurotic who contradicts the psychoanalysis). On the other hand, surrealism might become antipathetic for those people who react against the "conscious" content of the "surrealist message" which is "an inner and outer liberation of man from all his handcuffs". This "surrealist attitude" unifies against itself the majority part of the people of our époque - based on the way the developments 
have flown, the "suppression" of man against man is becoming more and more prominent. However, this situation is unacceptable for the surrealists and it can be shortly summarized in the sentence that the demand for freedom is absolute, inseparable and complete, and its objection in a certain field will influence even other ones. This means that the man, tangled in the crossroad of the issues of the time, has essentially lost himself and has abandoned the independent thought and the old habit to achieve to "conclusions" on his own. On the contrary he has to be "fed" with conclusions by the "specialists" so that he can accept everything without anxiety.

If we confused - as it often happens - surrealism with this way of thinking, with this "abandonment" of every independent character from other entire groups of intellectuals worldwide, this would be a serious mistake. The existence of a surrealist group "located" in France is sufficient to create the impression that all the surrealists worldwide, receive "didactical guidelines" form a café in Paris, where an assumed "World Movement" is led from. Every surrealist meeting has always had the character of a "friendly meeting" among the people who share the same preferences and present every idea, phrase, decision, criticism or concept in a dialectic conversation - which was often voted to get an important decision. Their applied criteria used to have the characteristic of an "elaborated consciousness" which was fully aware of the modern world. Furthermore, no "arbitrary" action in the field of ideas, was ever made without the appropriate and sufficient justification, particularly in cases when the relevant case was very complicated and it had some spiritual criteria.

They intended something more significant and complete, the gain of the "lost land" of humanity from the previous years this is a land which produces original artist children and spontaneous geniuses and the "previous peoples" the most prominent artists of the world. The surrealists themselves call the "esthetical criteria" "recognition of one's own self". They are fully conscious about what is happening inside them, they are aware of the fact if a product, a text, a painting or a sculpture, comes from the real source of one's own self.

Of course, it is not easy for one to present completely surrealist thesis, his experiences, techniques or his philosophical thesis - because at the end, something "enigmatic remains" from the entire hypothesis - something that exists or not something we cannot catch, just like the sneaky image of a lightning. Something that predicts something else that might be even bigger, more expanded and stronger - that means "the real recognition of surrealism is equal to a "catechism" (narration of the secret) - with a catechism taught to the Zen systems students, where the purpose of the spiritual and physical violence is carried out to remove the prejudices from their previous and conventional ideas and to prepare the "student" in advance to accept the "experience" of recognition.

\section{Concluding Remarks}

In conclusion, we would emphasize the fact that its value and presence are still current nowadays even though 5 decades have already passed from the last appearance of surrealism in Europe. Miltos Sachtouris, the Greek surrealist stated: "We will always need a heaven -the sky of surrealism ..." In an interview given, he responded to the question of today's surrealism: "Today it is not about surrealism, but rather its influence because the automatic writing and free coherences are not a game of style, they are a way to let things out of your unconsciousness on the surface, which does not mean that man liberated from his own unconsciousness those he disguised with surrealism. However, they did it more systematically and more convincingly, specifically, they were facing the problem and told us that we could not avoid it. ."1. "

During the social depression of all the society, the automatic writing would replace the psychological and the psychoanalytical treatments of the time; crazy love would fill in the empty spirit of the modern man that chases the technology and would help him to know his own self better, black humour would tragically fill in the pale panorama of the time where we live and would express the irony and the darkness of the modern days hypocrisy; and of course, the objective fortuity would prove that the entire life is an objective coincidence, where its flow and destiny are defined in the space.

1 http://www.tovima.gr/relatedarticles/article/?aid=91903 
Nowadays, surrealism globalization has artistic and spiritual values, as they would not help the man to change the world, not even life either, but would help him to alter his opinion and consequently, to alter his own self to live more poetically...

Because after all, today everyone may believe that everything happening seems to be only a dream:

"When I dream or I believe I dream, I am not in another world, says the surrealist, I am more than ever in this world, where reality is organized in a truly coherent way, but less coherent for me because it responds to my deepest desires. I attempt to make this moment of dreaming last longer, telling the dreams, stimulating insanity in order to build into the soul a crazy state" 1

\section{References}

[1] Benjamin Walter, Mythe et Violence, Publications Gallimard, Paris 1986

[2] Breton Andre, L' amour fou (1937), Publications Gallimard, Paris 1976

[3] Doctrine of Andre Breton in the Magazine Le grand jeu, published in Paris 1928

[4] Browder Clifford, "Andre Breton: Arbiter of Surrealism", Publications Droz, 1967

[5] Chassang Arsene, Senninger Charles, La Disertation Litteraire Generale, Volume 2, Publications Hachette, Paris 1993, Chapter XII, Le surrealisme

[6] Reverdy Pierre, L image, published in the Magazine Nord-Sud, No. 13, March 1918, in Nord-Sud, Self-Defense et autres ecrit sur I art e la poesie (1917-1926), Publications Flammarion, Paris 1975

[7] Rimbaud Arthur, Une saison en enfer, in Works, Publicationbs Garnier, Paris 1960

http://www.tovima.gr/relatedarticles/article/?aid=91903

1 Doctrine of Andre Breton in the Magazine Le grand jeu, published in Paris 1928 